\title{
Effect of Compensation and Competence on Employee Performance through Employee Development
}

\author{
Syahrir, Nasruddin, Mansur Azis \\ Sekolah Tinggi Ilmu Ekonomi AMKOP Makassar, Indonesia \\ syahrir@gmail.com,nasaruddin@gmail.com,mansurazis@yahoo.com \\ Khamo Waruwu \\ Universitas Tjut Nyak Dhien, Medan, Indonesia \\ waruwukhamo.se.mm@gmail.com \\ M Chairul Basrun Umanailo \\ Universitas Iqra Buru \\ chairulbasrun@gmail.com \\ Isnaniah Laili Khatmi Safitri \\ Manajemen Study Program, Faculty of Economics and Business \\ Medan Area University, North Sumatera, Indonesia \\ isnaniahlaili@gmail.com \\ Yusriadi Yusriadi \\ Sekolah Tinggi Ilmu Administrasi Puangrimaggalatung, Makassar, Indonesia \\ yusriadi.yusriadi@uqconnect.edu.au
}

\begin{abstract}
This study analyzes the effect of compensation and competence on employee performance through employee development at the Tourism Office in Bantaeng Regency. It conducted this research for two months; this study's population were all employees of the Bantaeng Regency Tourism Office as many as 96 people, the hypothesis that has been proposed, the path analysis technique, and the Sobel test were carried out. The result of his research is that compensation has a positive and significant effect on employee development at the Bantaeng Regency Tourism Office. Competence has a positive and significant impact on employee development and substantially impacts employee performance at the Bantaeng Regency Tourism Office. Compensation has a positive and significant effect on employee performance, and employee development has a positive and significant impact on employee performance at the Bantaeng Regency Tourism Office. And competence has a positive and insignificant effect on employee performance through employee development, and compensation has a positive and negligible impact on employee performance through employee development at the Bantaeng Regency Tourism Office.
\end{abstract}

Keywords:

Compensation, Competence, Development, Performance, Indonesia

\section{Biographies}

Syahrir is a student at Magister Program of Economic Science of STIE AMKOP, Indonesia. His areas of interest and research include social science and economic. He has published some articles in national journals. 
Nasruddin is a lecturer at Economics Department of STIE AMKOP, Indonesia. His areas of interest and research include economic, management, management human resource. He has published some books and many articles in national and international journals.

Mansur Azis is a lecturer at Economics Department of STIE AMKOP, Indonesia. His areas of interest and research include economic, management, management human resource. He has published some books and many articles in national and international journals.

Khamo Waruwu is a lecturer at the Faculty of Economics, Department of Management, Universitas Tjut Nyak Dhien, Medan, Indonesia. Research fields and interests include social sciences, has published several scientific articles in national journals, has attended CPHCM Non-Academic Degree Professional Training (Certified Professional Human Capital Management) organized by IHRCI 2020. Active in several organizations such as the Medan branch of the ISEI (Indonesian Economists Association), the Medan branch of the PDRI (Indonesian Lecturer Brotherhood), and the Medan branch of the ISRI (Indonesian Bachelor Association).

M Chairul Basrun Umanailo has worked as a Lecturer at Iqra Buru University since 2011 until now he is still active in the University's academic activities. has served as head of the Centre for Planning and Community Development Studies (PSP2M) since 2018. Completed his master's program at Sebelas Maret University in 2016, is currently still completing research on the conversion of agricultural land functions.

Isnaniah Laili Khatmi Safitri Completed a bachelor's degree in management study program from the Islamic University of North Sumatra in 1992 and a master's degree in agribusiness management from the Medan Area University in 2008.

Yusriadi Yusriadi is a lecturer at Public Administration Department of Sekolah Tinggi Ilmu Administrasi Puangrimaggalatung, Indonesia and chancellor on Sekolah Tinggi Ilmu Hukum Pengayoman. His areas of interest and research include social science, political science, sociology, legal studies, and public administration. He has published some books and many articles in national and international journals. He is a reviewer and editor in some local and international journals. 